\title{
Revisit Adjective Distribution in Chinese
}

\author{
LI Wenchao \\ University of Zhejiang, China \\ widelia@zju.edu.cn
}

\begin{abstract}
This study re-classifies Chinese monosyllabic adjectives and verbs in light of 'scale structure'. It examines how various adjectives are associated with different scalar layers of verbs. The investigation focuses upon direct perception expressions and resultatives. The finding reveals that the closed-scale perceptual verb jiàn 'see' does not tolerate open-scale APs. This is because, (a) syntactically, Chinese perception verb complements do not represent a result state as the APcomplement is encoded into the perception verb root; (b) semantically, jiàn 'see' not only represent an accomplishment predication but contributes to a potential indirect perception, describing the observer's evaluation of the perceived event. kàn 'look' is open-scale and is likely to render a direct perception report. The degree of kàn's associations with different APs runs from 'Totally open-scale $A P^{\prime}$ ', down to 'Upper closed-scale AP', 'Lower closed-scale AP', 'Totally closed-scale AP'. Resultatives seem to welcome all layers of adjectives. Various APs may match with a transitive verb, an unergative verb, a light verb or an unaccusative verb. This is down to the fact that, resultative complements are framed outside the verb roots and thus, do not receive restriction from the verb.
\end{abstract}

Keywords: scale structure; adjective distribution; Chinese

\section{Povzetek}

Raziskava ponudi prerazvrstitev kitajskih enozložnih pridevnikov in glagolov po teoriji skalarnih struktur. V njej se avtorica posveča izrazom neposrednega zaznavanja in rezultativnim izrazom ter preuči načine, s katerimi se pridevniki preko različnih skalarnih nivojev navezujejo na glagole. Rezultati kažejo, da na primer zaprti tip glagola zaznavanja jiàn 'videti' ne sprejema odprtega tipa pridevniškega dopolnila. Vzroka za to sta dva. Prvi vzrok je sintaktični; kitajska dopolnila glagolov zaznavanja namreč ne izražajo rezultatske vsebine, saj je pridevniško dopolnilo vključeno že $v$ glagolski osnovi. Drugi vzrok je semantični; glagol jiàn 'videti' predstavlja ne samo predpostavlja izpolnitev, ampak tudi prispeva k možni posredni zaznavi, saj opisuje opazovalčevo oceno zaznanega dogodka. Odprti tip glagola kàn 'gledati' po drugi strani zagotavlja neposredno poročilo o zaznavi. Stopnje povezanosti glagola kàn 'gledati' z različnimi pridevniškimi obrazili se lahko zelo različne; od popolnoma odprtega do popolnoma zaprtega odnosa. Rezultativni glagoli sprejemajo vse pridevnike, ker se rezultativna določila pojavljajo zunaj glagolskih osnov in zato niso omejena z značilnostmi samega glagola. Različna pridevniška obrazila se tako lahko vežejo s prehodnimi glagoli, pravimi neprehodnimi glagoli, netožilniškimi glagoli in glagoli z oslabljenim pomenom.

Ključne besede: skalarna struktura; porazdelitev pridevnikov; kitajski jezik

Acta Linguistica Asiatica, 7(2), 2017.

ISSN: 2232-3317, http://revije.ff.uni-lj.si/ala/

DOI: 10.4312/ala.7.2.85-109 


\section{Introduction}

Chinese is alleged to be a Sino-Tibetan language. Adjectives are of four subtypes: (i) one-syllable adjectives, e.g. 好 hăo 'good'; (ii) two-syllable adjectives, e.g. 干净 gānjìng 'clean'; (iii) overlapping of two-syllable adjectives, e.g. 干干净净 gāngān-jìngjìng 'clean' and (iv) three-syllable adjectives, e.g. 滑溜溜 huá liūliū 'skittery'.

One-syllable adjective

$\begin{array}{lllll}\text { (1) 妈妈 } & \text { 烤 } & \text { 好 } & \text { 了 } & \text { 蛋糕。 } \\ \text { māma } & \text { kăo } & \text { hăo } & \text { le } & \text { dàngāo. } \\ \text { mother } & \text { bake } & \text { RESULT.COMP } & \text { PERF } & \text { cake }\end{array}$

'Mother has baked the cake.'

Two-syllable adjectives

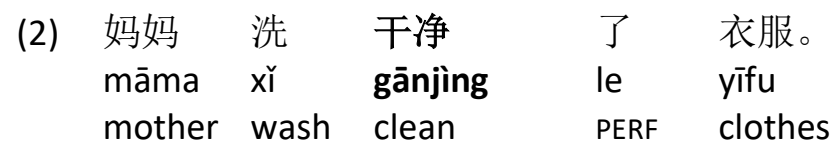

'Mother has done the laundry.'

Overlapping of two-syllable adjectives

(3) 那个 戴 眼镜 的 学生, 衣服 总是 干干净净 的。 nàgè dài yănjìng de xuésheng ȳifu zŏngshì gāngān-jìngjìng de. DEM wear glass NLZR student clothes always neat and tidy EXCL 'The student, who wears glasses, always seems neat and tidy.'

Three-syllable adjectives
(4) 肥皇 湿
了
以后, 变
得 滑溜溜。
féizào shī
le y̆hòu, biàn
de huá liūliū
soap (get) wet PERF after become ADV skitter
'Once the soap is wet, it becomes skittery.'

There are three ways of denoting a perceptual result in Chinese, i.e. an infinitival VP (5a), an adjectival complement (5b), or a locative adjunct (5c).
(5)
a. 张三
看见
他 买 衣服 ${ }^{1}$ 。
(infinitival VP)
Zhāngsān kànjiàn tā măi yîfu
Zhangsan look-see him buy clothes
'Zhangsan saw him buy clothes.'

\footnotetext{
${ }^{1}(5 a)$ can also be treated as being denoted by a gerund VP, i.e. 'Zhangsan saw him buying clothes'. Moreover, a reviewer pointed out that (5a) is a serial verb construction (c.f. Westermann, 1930; Stewart, 1963; Bradshaw, 1982; Griffiths, 1991; Collins, 1993; Andrews, 1997; Aikhenvald, 1999, 2006; Foley, 2009). Our position is that although SVC existed in Old Chinese, where monosyllabic roots played the essential role, it started declining during Middle Chinese and has been completely lost in Contemporary Chinese. Li (to appear) proposes that an SVC must meet the following conditions: (a) semantically, the events rendered by the multiple verbs are either successive or
} 

b. 张三 看三他 裸 着。 (adjectival complement)
Zhāngsān kàn tā luǒ zhe
Zhangsan look.PAST him naked PROG
'Zhangsan saw him being naked.'
c. 张三 看见 他 在 酒吧。(locative adjunct)
Zhāngsān kànjiàn tā zài jiǔba
Zhangsan look-see him PREP pub
'Zhangsan saw him in the pub.'

In Chinese direct perception expressions, two issues in particular are worthy of discussion. First, not all adjectival perceptual complements are licensed in direct perception expressions, The following AP 裸 luǒ 'naked' seems unable to perform as the complement for 看 kàn 'look'.
(6) a.*张三 看 狗 死了。 (ill-formed)
Zhāngsān kàn gǒu š̀ le
Zhangsan look dog dead past
'*Zhangsan watched the dog dead.'

The following expression is rendered by the same AP but appears natural.
(6)
Zhāngsān jiàn gǒu š̀ le
Zhangsan see dog dead past
b. 张三 见 狗死了。 (well-formed)
'Zhangsan saw the dog dead.'

The ungrammaticality of (6a), if supplemented with an addition of syntactic context (e.g. a locative adjunct or an adverb), can be improved, as shown in (7).
（7）张三 看 狗 死 在路边。 (well-formed)
Zhāngsān kàn gǒu sǐ zài lù biān
Zhangsan look dog dead by the road
'Zhangsan looks at the dog which has died at the side of the road.'

The different treatments in (6a)-(7) are possibly down to the scalar property of adjectives and perceptual verbs. It should be further pointed out that during the preQin period, Chinese perceptual verbs were conveyed by monosyllabic roots. In the Early Han Dynasty, disyllabic word roots occurred and by the Middle Han Dynasty, verb compounds started to play a significant role. In Modern Chinese, three perceptual verbs co-exist, i.e. 看 kàn 'look', 见jiàn 'see', 看见 kànjiàn 'look-see'. 看 kàn behaves 
like an action verb, corresponding to the English 'look/watch' or the Japanese transitive verb '見る miru'. 见 jiàn is likely to indicate the result of a perceived event. It corresponds to the Japanese unaccusative verb '見える mieru' and English 'see'. 看见 kànjiàn 'look-see' is a resultative compound verb (V-V). The first constituent 看 kàn denotes the perception action; the second constituent 见 jiàn renders the result of the perceived event.

The purpose of this paper is two-fold. First, the scalar property of adjectives and verbs in Chinese is revisited, followed by a re-classification of AP and V, which differs from traditional categorisation. Then we discuss how various layers of adjectives distribute in direct perception expressions and resultatives.

To consider the above issues, this paper is mapped out as follows: Section 1 sets the stage for what follows by giving a brief introduction to adjective distribution in direct perception expressions as well as resultatives in Modern Chinese. Section 2 revisits Chinese verbs and mono-syllabic adjectives. Section 3 tackles the question on how adjectival complements are treated in direct perception expressions. Section 4 delves into the distribution of adjectives in resultatives. Section 5 highlights the results and concludes the paper.

The perception expressions and resultative constructions tackled in this study are confined to the form of $N_{1} V N P_{2} A P$, where the $A P$ is a one-syllable adjective predicated of $\mathrm{NP}_{2}$. The verb in resultatives is monosyllabic. In perception expressions, three verbs contribute to the perceptual event.

The data for Modern Chinese is adopted from the corpus of Modern Chinese constructed by the Center for Chinese Linguistics at Beijing University. See http://ccl.pku.edu.cn/. This study also uses hand-made examples.

\section{Framework: scale structure}

The scale structure framework is adopted to help us to measure the scalar properties of various grammatical elements, i.e. verbs, adjectives and copular verbs. The term scale was initially put forward by Sapir (1944). During the 1970s, it was mainly adopted in formal semantics (Bolinger, 1972). In the 1990s, scale was introduced to the study of syntax (Hay et al., 1999). Recently, Kennedy and McNally (2005) developed its use in the study of lexical semantics and introduced 'scale structure' into the study of resultatives. Accordingly, a scale is constituted of a set of degrees (points or intervals indicating measurement values) on a particular dimension (e.g. cost, depth, height, temperature), with an ordering relation. The dimension represents an attribute of an entity, with the degrees indicating the possible values of this attribute (Kennedy \& McNally, 2005). 
Scale measures the change undergone by the incremental theme, patient or figure participant. It may have the following variations:

(a) totally open-scale: a scale may have neither a minimal nor maximal element;

(b) lower closed-scale: a scale may have a minimal but no maximal element;

(c) upper closed-scale: a scale may have a maximal but no minimal element;

(d) totally closed-scale: a scale may have both maximal and minimal elements.

Kennedy and McNally (2005)

The scalar properties of APs and (pre) postpositions further link to the combinatorial possibilities with verbs. Wechsler (2005, p. 264) indicates that resultative constructions with maximal endpoint adjectives often have durative verbs, e.g. wipe, pull. On the other hand, non-gradable adjectives are more likely to occur with punctual verbs, e.g. shoot, kick. This view is supported by Beavers (2008), who proposes that punctual verbs tend to yield non-gradable de-verbal adjectives while durative verbs tend to yield gradable de-verbal adjectives.

With this in place, the 'scale structure' framework may help us measure the scalar properties of various grammatical elements.

\subsection{The scalar property of Chinese mono-syllabic adjectives}

To account for the adjective distribution in Chinese, it is essential to revisit adjectives. Below is a list of monosyllabic adjectives that are mostly employed to convey the perceptual results.

累 lèi / 紧张 jǐnzhāng / 疯 fēng / 伤心 shāngxīn / 破 pò / 旧 jiù / 醉 zuì / 苍白 cāng bái / 纯 chún /密 mì / 裸 luǒ / 死 sǐ / 空 kōng

This study uses the modifiers, i.e. 很 hěn 'very', 完全 wánquán 'completely' and 有 一点儿 yǒu yīdiănr 'a bit', to diagnose their scalar properties. The results are summarised in (8).

(8) (i) 很 hěn

累 lèi / 疯 fēng / 破 pò / 旧 jiù / 醉 zuì / 纯 chún / 密 mì / ? 裸 luǒ /

*死 sǐ / *空 kōng

very tired / crazy / broken / shabby / drunk / pure / thick / ?naked /

*dead / *empty

(ii) 完全 wánquán

*累 lèi / 疯 fēng / *破 pò / *旧 jiù / 醉 zuì / * 纯 chún / *密 mì / 裸 luǒ / 死 sǐ / 空 kōng 
completely

*tired / crazy / *broken / *shabby / drunk / * pure / *thick / naked / dead / empty

(iii) 有一点儿 yǒu yīdiănr

累 lèi / ? 疯 fēng / 破 pò / 旧 jiù / 醉 zuì / * 纯 chún / *密 mì / *裸 luǒ /

*死 š / *空 kōng

a bit

tired /? crazy / broken / shabby / drunk / *pure / *thick / *naked /

*dead / *empty

Building on this, we arrive at a four-layer classification of perceptual APs:

(9) a. totally open-scale: 累 lèi 'tired, 疯 fēng 'crazy';

b. lower closed-scale: 破 pò 'broken', 旧 jiù 'shabby', 醉 zuì 'drunk';

c. upper closed-scale: 纯 chún 'pure', 密 mì 'thick', 裸 luǒ 'naked';

d. totally closed-scale: 死 sǐ 'dead'2, 空 kōng 'empty'.

Moving on to monosyllabic adjectives that render resultative results, the modifiers 很 hěn 'very', 完全 wán quán 'completely', and 有一点儿 yǒu yī diănr 'a bit', helped us with the diagnosis. The results are provided in (10).

\section{(10) (i) 很 hěn}

长 cháng / 贵 guì / 深 shēn / 累 lèi / 平 píng / 苦 kǔ / 破 pò / 湿 shī /

硬 yìng / *死 š / *空 kōng / *光 guāng

very

long / expensive / deep / tired / flat / bitter / broken / wet /

hard / *dead / *empty / *bare

(ii) 完全 wánquán

*长 cháng / *贵 guì / *深 shēn / *累 lèi / 平 píng / *苦 kǔ / 破 pò / 湿 shī /

*硬 yìng / 死 š̌ / 空 kōng / ?光 guāng

\footnotetext{
${ }^{2}$ Another possible interpretation is that 死 š̌ is a verb with inherent resultative meaning, which is a different view from the one in this paper. Indeed, unlike Indo-European languages, where part of speech corresponds to grammatical functions, the category of Chinese is rather vague, which is due to the lack of inflectional morphology. There has been a long-term debate on the classification of lexical categories (Ma (1898); Karlgren's (1949, p. 68); Wang (1957, 1958); Chao (1968, pp. 498815); Fan (2005); Che (1981); Shen (2009), among others). This study adopts functional criteria as the starting point, and combines semantic factors. It defines an intransitive verb as a verb that does not take a direct object and can not be modified by an adverb. Note that very few intransitive verbs in Chinese can take objects that behava like a VP and license two arguments. However, they do not function as causative verbs but rather, they denote a sense of an indirect passive voice. An adjective is a lexeme that denotes a descriptive property and that can be used attributively before a noun as in example 死人 sirén (a dead person, $\mathrm{Adj}+\mathrm{N}$ ). With this in place, it seems proper to deem 死 sǐ as an adjective; rather than an intransitive verb.
} 


\section{completely}

*long / *expensive / *deep / *tired / flat / *bitter / broken / wet /

*hard / dead / empty /?bare

(iii) 有一点儿 yǒu yīdiănr

长 cháng / 贵 guì / 深 shēn / 累 lèi / 平 píng / 苦 kǔ / 破 pò / 湿 shī /

硬 yìng / *死 sǐ / *空 kōng / *光 guāng

a bit

long / expensive / deep / tired / flat / bitter / broken / wet /

hard / *dead / *empty / *bare

Incorporating this, the following four variations of resultative APs are proposed:

(11) a. Totally open-scale: 长 cháng 'long', 贵 guì 'expensive', 深 shēn 'deep', 累 lèi 'tired';

b. Lower closed-scale: 苦 kǔ 'bitter', 破 pò 'broken', 湿 shī 'wet';

c. Upper closed-scale: 硬 yìng 'hard', 平 píng 'flat';

d. Totally closed-scale: 死 š̌ 'dead', 空 kōng 'empty', 光 guāng 'bare'.

\subsection{The scalar property of Chinese monosyllabic verbs}

Having demonstrated the adjectives in resultatives and perceptions, this section moves on to examine how verbs might be sensitive to the 'scale structure'.

Traditionally, verbs are classified according to the internal temporal structure of the events they describe. The most representative diagnosis is the aspectual classification (Vendler, 1967). Accordingly, English verbs can be classified into four types in terms of dynamicity, duration and telicity. Examples are shown in (12).

(12) state verb: love, hate

activity verb: hit, walk

accomplishment verb: paint, draw

achievement verb: arrive, reach

Applying the equivalent classification of (12) to Chinese would give the following result (13).

(13) state verb: 爱 ài 'love'

activity verb: 揍 zòu 'beat'

accomplishment verb: 画 huà 'draw'

achievement verb: 到 dào 'arrive'

Testified by the adverbials 完全 wánquán 'completely' and 一直 yīzhí 'keep doing', Chinese verbs present the following characters. 
(14) (i) 完全 wánquán

进 jìn / 出 chū / 过 guò / 到 dào / * shàng / *下 xià /*切 qiē / *揍 zòu /

*砍 kăn

completely

enter / exit / cross / reach / *ascend / *descend / *cut / *beat /

*chop

(ii) 一直 yīzhí

*进 jìn / *出 chū / *过 guò / * 到 dào / 上 shàng / 下 xià / 切 qiē / 揍 zòu / 砍 kăn

keep doing

*enter / *exit / *cross / *reach / ascend / descend / cut / beat / chop

The above variations are summarised in Table 1.

Table 1: Illustrations of new classification

Verbs

完全 一直
'completely' 'keep doing'

Scalar property

(i) Scalar change

(a) 进 jìn, 出 chū 'exit', 过 guò 'cross', 到 dào 'reach'

○ $\times$ totally closed-scale

(b) 上 shàng 'ascend', 下 xià 'descend', 升 shēng 'ascend'

$\times \quad 0 \quad$ open-scale

(c) 切 qiē 'cut', 揍 zòu 'beat, break', 砍 kăn 'chop'

$\times \quad \circ \quad$ upper closed-scale

(ii) Non-scalar change

爱 ài 'love', 恨 hèn 'hate'

○

non-scalar change

In the group (a): 进 jìn 'enter', 出 chū 'exit', 过 guò 'cross', 到 dào 'reach' are punctual verbs, bearing an endpoint. They may be modified by the adverb 完全 wánquán 'completely'. In the corpus CCL, there are three tokens of 完全出 wánquán chū, two tokens of 完全过 wánquán guò and, three tokens of 完全到 wánquán dào. 完全进入 wánquán jìnrù seems better than 完全进 wánquán jìn. Here 入 rù functions as a directional complement. Since Early Han Dynasty, 入 rù has been grammaticalised and changed from an intransitive or transitive verb into a complement. It retains the substantive transitive function only when its meaning is lexicalised, e.g. 入契 rù zhui 'marry into and live with one's bride's family'. 出 chū 'exit', 过 guò 'cross' and 到 dào 'reach' have been partially grammaticalised but their verb function retain. In the corpus $\mathrm{CCL}$, there are three tokens of 完全出 wánquán chū, two tokens of 完全过 wánquán guò and, three tokens of 完全到 wánquán dào. 
In Group (b): 上 shàng 'ascend', 下 xià 'descend'3', 升 shēng 'ascend' can be modified by 一直 yīzhi 'keep doing', e.g. 一直升 yīzhí shēng 'keep rising'.

In Group (c), 切 qie 'cut', 揍 zòu 'beat, break', the verbs are action verb and do not indicate an endpoint. They can be modified by 一直 yīzhi' 'keep doing but cannot occur with '完全 wánquán (completely)'. When adding a resultative complement (e.g. 好 hăo, 满 măn, 光 guāng) to verbs 切 qiē 'cut' and 揍 zòu 'beat, break', these action verbs can be modified by the adverb 完全 wánquán 'completely', c.f. the supplement provides the result of the action. The lexical conceptual structures of 切 qie 'cut' and 切好 qiēhăo 'cut-finished' are given in (15).
a. 切 qiē:
$x$ CONTROL [ $y$ BECOME $[y$ BE AT-z] ]
b. 切好 qiēhăo:
$x$ CONTROL $\left[y\right.$ BECOME $\left[\begin{array}{lll}y & \text { BE AT- } z]\end{array}\right] \quad(x=y)$

(15a) and (15b) are actually transitive/intransitive alternation. The alternation process can be described as follows:

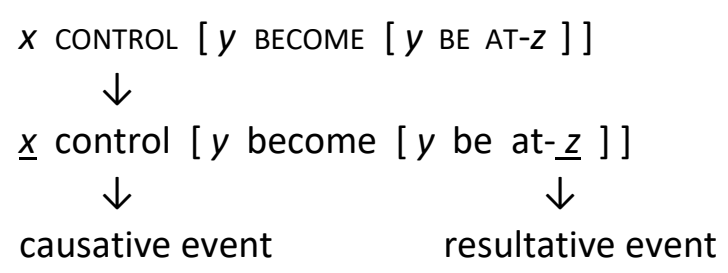

Building on this, we re-classify Chinese verbs into two macro groups, i.e. scalar change verbs and non-scalar change verbs. Scalar change verbs can be divided into: open-scale verb, upper closed-scale verb and totally closed-scale verb. The classification is summarised in Figure 1.

\footnotetext{
${ }^{3}$ There is a possibility that the expression 下 xià gets modified by 完全 wánquán as in 太阳完全 下了 tàiyáng wánquán xià le (the sun descended completely). However, the sentence sounds odd and could be improved by 太阳完全下了(山/湖面) 'the sun descended completely (behind hills/lake)'. 下 xià in this expression is lexicalised. Other such examples are 下海 xià haĭ 'go into business', 出国 chū guó 'go abroad' where 出 chū gets lexicalised, and others. The motion verbs tackled here are delimited to their original function and meaning.
} 


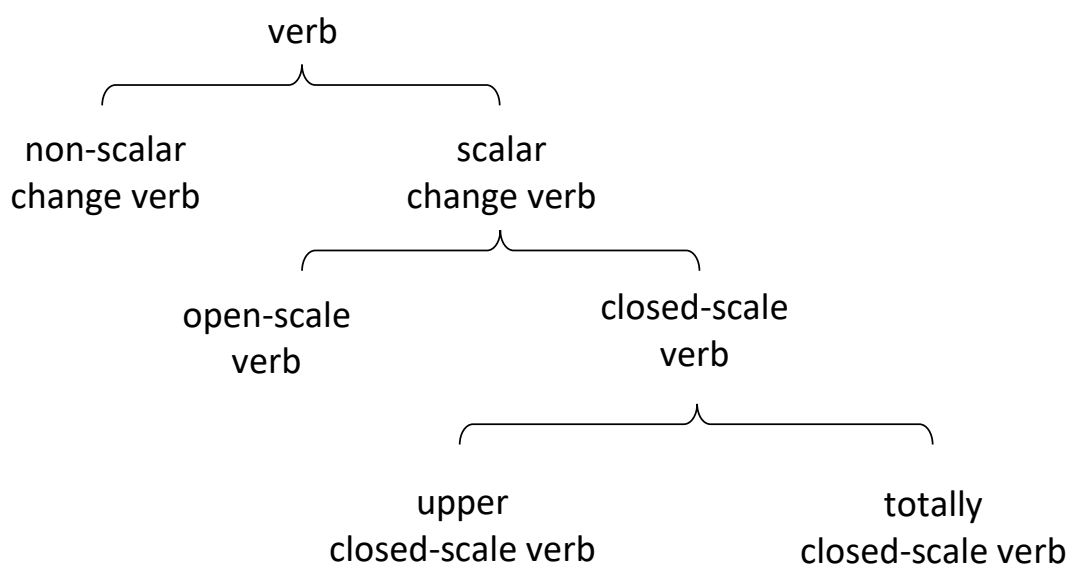

Figure 1: Classifications of Chinese verbs in light of scale structure

\section{Adjective distribution in direct perception expression}

With the classifications of adjectives and verbs highlighted, the following sections proceed, posing the questions of (a) how different layers of perceptual APs associate with different perceptual verbs; (b) how adjectival complements show sensitivity to the scalar structure in resultatives. Discussions start from the adjective distribution in direct perception expressions.

As touched upon in earlier, there are three perceptual verbs, i.e. 看 kàn 'look', 见 jiàn 'see', 看见 kànjiàn 'look-see'. In light of 'scale structure', they have the following distinctions. 看 kàn is an open-scale morpheme while 见 jiàn bears closed-scale character. The resultative verb compound 看见 kànjiàn 'look-see' is closed-scaled. The scalar property of each verb is summarised in (16).

(16) Scalar property of Chinese perceptual verbs

a. 看 kàn: open-scale, corresponding to English 'look'

b. 见 jiàn: closed-scale, corresponding to English 'see'

c. 看见 kànjiàn: resultative compound verb [action + result]; closed-scale, corresponding to English 'see'

It occurs that upper closed-scale APs do not match well with closed-scale perceptual verbs, e.g. (17). 
(17) Upper closed-scale AP + closed-scale perceptual V



The oddness of (17) has to do with the perceptual verb 见 jiàn 'see'. As a closed-scale constituent, 见 jiàn requires a complement that contains an endpoint. Given that 裸 luǒ 'naked' is not a totally closed-scale constituent, (17) is unnatural. If, however, supplying the expression with a tense or a syntactic context, the oddness will be mended, c.f. (18).

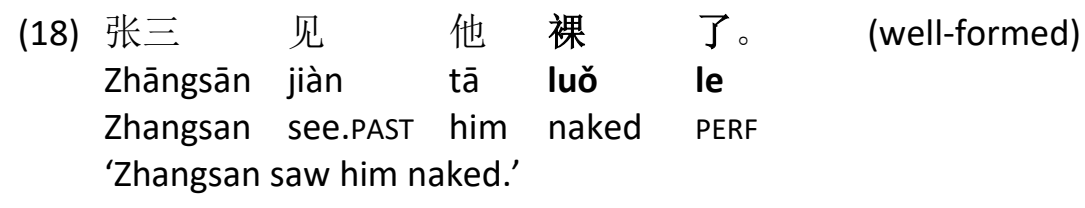

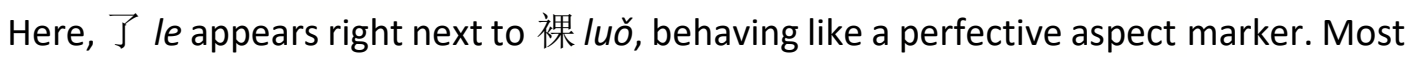
crucially, it functions on the perceptual complement, i.e. 裸 luó (naked) rather than the perceptual verb from the main clause, i.e. 见 jiàn 'see'. Given this, the sub clause, i.e. 他裸了 tā luǒ le '(saw) him naked' in (18) turned into a closed-scale event and can be interpreted as an EVENTUALITY expression. The illustration in (19) is a combination of an upper closed-scale AP and an open-scale perceptual verb.

Upper closed-scale AP + open-scale perceptual V

$\begin{array}{llll}\text { (19) a. *张三 看 他 裸。 } & \text { (ill-formed) } \\ \text { Zhāngsān kàn tā luǒ } & & \\ \text { Zhangsan look.PAST him naked } & & \\ \text { 'Zhangsan sees him naked.' } & & \\ \text { b. 张三 看 } \quad \text { 他 裸 } & \text { 着。 } & \text { (well-formed) } \\ \text { Zhāngsān kàn tā luǒ zhe } & \\ \text { Zhangsan look.PAST him naked } & \text { PROG } & \\ \text { 'Zhangsan saw him being naked.' } & \end{array}$

It appears that upper closed-scale APs cannot be tolerated by open-scale perceptual Vs. The additional progressive marker 着 zhe in enables the upper closed-scale AP temporarily transit into an open-scale AP (c.f. 19b). Thus, the event turns into a totally open-scale STATE. Another way to improve the illness of [upper closed-scale AP + openscale perceptual $\mathrm{V}]$ is by supplying it with an adjunct, c.f. (20).
(20) 张三
*看/见他
裸
luǒ
着上半身。
Zhāngsān
kàn/jiàn tā
zhe shàng bàn shēn
Zhangsan
look/see him naked
prog upper body
'Zhangsan watched/saw him half naked.' 
The adjunct 裸着上半身 luǒ zhe shàng bàn shēn 'being half naked' is closed-scaled. The sub clause 他裸着上半身 tā luǒ zhe shàng bàn shēn 'him half naked' can be tackled as an EVENTUALITY expression and thus is capable to combine with a closed-scale verb (见 jiàn 'see'). The closed-scale EVENTUALITY expression fails to match with the open-scale verb 看 kàn (c.f. 20).

Upper closed-scale APs seem possible to associate with the closed-scale perceptual V-V, 看见 kànjiàn, as exemplified by (21).

$\begin{array}{llll}\text { (21) 张三 } & \text { 看见 } \quad \text { 他 裸。 } & \text { (well-formed) } \\ \text { Zhāngsān kànjiàn tā luǒ } & \\ \text { Zhangsan look/see him naked } & \\ \text { 'Zhangsan sees him naked.' } & \end{array}$

Below is an illustration of [totally closed-scale AP + closed-scale V].

Totally closed-scale AP + closed-scale V
(22) 张三 狗 死。
Zhāngsān jiàn gǒu sì
Zhangsan see dog dead
'Zhangsan sees the dog dead.'

死 si here can have two functions, either as an adjective ${ }^{4}$ as in example (22) or as a verb as in example (23). If tackling 死 si as a closed-scale adjective, (22) would entail the following nuance: Zhangsan perceived the STATE of the dog, i.e. being dead. If tackling 死 si as a verb, the tense marker 了 le is obligatory in the perception expression, c.f. (23).

$\begin{array}{llllll}\text { (23) 张三 } & \text { 见 } & \text { 狗 } & \text { 死 } & \text { 了。 } & \text { (tense addition: obligatory) } \\ \text { Zhāngsān jiàn gǒu sǐ le } & \\ \text { Zhangsan see dog die } & \text { PAST } & \\ \text { 'Zhangsan sees the dog has died.' } & \end{array}$

\footnotetext{
${ }^{4}$ Due to the lack of inflectional morphology, the classification of lexical categories has been debated a good deal (Wang, 1957, 1958; Zhu, 1982; Chao, 1948, 1968; Packard, 2000, etc). Ma Jianzhong's pioneering work 'Mashi Wentong' (1898) argues that western categories of word classes can be applied to Chinese. Karlgren (1949, p. 68) and Maspero (1934, p. 35) consider Chinese to be a language with no distinct word classes. Chao (1968, pp. 498-815), in his Grammar of Spoken Chinese, tries to define word classes in Chinese, but he is unable to come up with concrete criteria for doing so. This study adopts functional criteria as the starting point and combines semantic factors. It is argued that 'an adjective is a lexeme that denotes a descriptive property and can be used attributively before a noun: $\mathrm{Adj}+\mathrm{N}$ '. 'An adjective is also a word that can be modified by words 很 hěn, 非 fëi cháng 'very' with the word order '很 + Adj". The relative marker 的 de may be added after the word: $\mathrm{Adj}+$ 的 $+\mathrm{N}$ though it 3 is not always required.
} 
The tense marker 了 le indicates the endpoint of the ACTION, i.e. 死 si 'die'. Apart from the tense marker 了 le, an addition of adjuncts such as 在路边 (zài lù biān 'by the road') may also provide an endpoint to the perceived event, c.f. (24).

(24) 张三 见 狗 死 在路边。 (adjunct addition)
Zhāngsān jiàn gǒu sì zài lù biān
Zhangsan see dog die by the road
'Zhangsan saw the dog die by the road.'

The adjunct provides extra information about the location that the sub clause (i.e. 狗 死 the dog die) takes place.

By adding the tense marker, adjunct indicates an accomplishment of the sub clause, which ensures the perceived event to be an EVENTUALITY expression. As a result, they are possible to co-occur with the closed-scale perceptual verb 见 jiàn 'see'.

On the other hand, it is not very likely that the open-scale perceptual verb would combine with a totally closed-scale AP, as shown in (25).

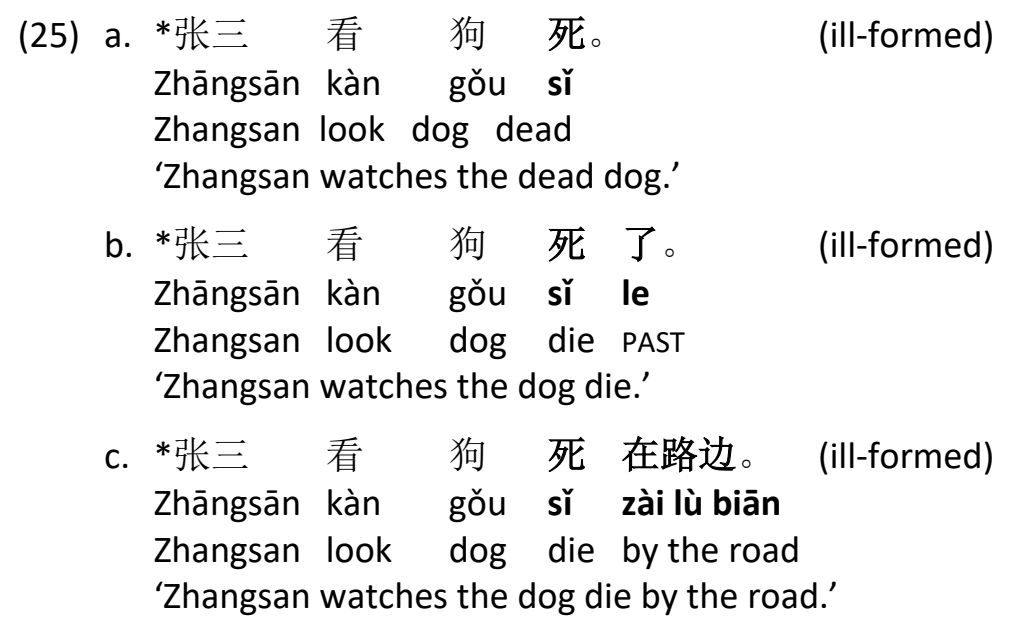

The closed-scale perceptual V-V (看见 kànjiàn 'look-see'), however, may well form with a totally closed-scale AP, as illustrated in (26).




c. 张三 看见 狗 死 在路边。 (well-formed)

Zhāngsān kànjiàn gǒu sǐ zài lù biān

Zhangsan look-see dog die by the road

'Zhangsan saw a dead dog by the road.'

The reason for the well-formed combination of the closed-scale perceptual V-V with a totally closed-scale AP lies in that the perceptual V-V 看见 kànjiàn 'look-see' is rightheaded. Therefore, the scalar property relies on the second constituent, i.e. 见 jiàn 'see'. 见 jiàn determines which adjectival complement to take.

Lower closed-scale APs do not seem possible to associate with closed-scale perceptual verbs, as exemplified by (27).

Lower closed-scale AP + closed-scale V
(27) ?张三 见 房屋破。
Zhāngsān jiàn fáng wū pò
Zhangsan see house damaged
'Zhangsan sees the house damaged.'

If supplied with another AP, i.e. 旧 jiù 'shabby', the oddness would be improved, as in (28).
(28) 张三 见 房屋破旧。 (better)
Zhāngsān jiàn fáng wū pòjiù
Zhangsan see house damaged-shabby
'Zhangsan sees the house damaged and shabby.'

The improvement can be explained from a semantic point of view. As a lower closedscale AP, 破 pò 'damaged' solely conveys an objective description about the appearance of the house. Thus, it fails to co-occur with a closed-scale perceptual verb. On the other hand, although 旧 jiù 'shabby' is also a lower closed-scale AP, it does not only render a perception action but also conveys the perceiver's evaluation of the object (i.e. shabby). Moreover, from a prosodic point of view, (28) sounds more appropriate. At any rate, the combination of 旧 jiù 'shabby' is accepted. With this in place, we may possibly deduce that the closed-scale perceptual verb 见 jiàn 'see' is somehow subjective.

Likewise, the adverbial 很 hern 'very' may also improve the unnaturalness of the expression a great deal, c.f. (29).
(29) 张三 见 房屋 很
Zhāngsān jiàn fáng wū hěn
Zhangsan see house extremely damaged
'Zhangsan sees the house extremely damaged.' 
Adding the modifier 很 hěn 'very' provides an endpoint to the open-scale AP. 很破 hěn pò 'extremely damaged' turns into a boundary predicate and is therefore licensed by the closed-scale perceptual verb 见 jiàn 'see'.

This phenomenon comes to resemble German perceptual verb sehen. The illformed German expression: 'Mary sah den Jungen traurig (Mary saw the boy sad) can be improved by an extra adverb or a syntactic context, as in (30b).
a. *Mary sah den Jungen traurig.
Mary see.PAST the boy sad
'Mary saw the boy sad.'
b. Mary sah den Jungen traurig am Tisch sitzen. (well-formed)
Mary see.PAST the boy sad at table sit
'Mary saw the boy sitting at the table, looking sad.'

Open-scale adjectival perception verb complements are ruled out by German perceptual verb sehen and Chinese closed-scale perceptual verb 见 jiàn 'see'. Openscale adjectival perception verb complements may invite temporary predications only by the addition of a syntactic context. Syntactic context enables the German sehen and Chinese 见 jiàn 'see' to make a conceptualisation of the perceived event, offering an 'evaluation'. The conclusion we may draw from the picture outlined here is that syntactically, Chinese and German perception verb complements do not represent a result state as the AP-complement is encoded into the perception verb root. Chinese and German perceptual verbs, i.e. 见 jiàn 'see' and sehen represent not only a predication of accomplishment but contribute to a potential indirect perception by describing the observer's conceptualisation of the perceived event and thus offering an 'evaluation' or 'interpretation'. On the other hand, the open-scale perceptual verb 看 kàn 'look' denotes a direct perception report and requires the sub-event to a state predication.

Incorporating this, we may explain the ill-formedness of lower closed-scale APs with open-scale perceptual verb 看 kàn 'look', c.f. (31).

Lower closed-scale AP + open-scale V

(31) *张三 看 房屋 破/旧。 (ill-formed)
Zhāngsān kàn fáng wū pò/jiù
Zhangsan look house damaged/shabby
'Zhangsan watches the damaged/shabby house.'

The lower closed-scale AP 破 pò 'damaged' seems incapable to combine with the closed-scale V-V 看见 kànjiàn 'look-see' (32a). Intriguingly, the combination of V-V and another lower closed-scale AP 旧 jiù 'shabby' appears better (32b). The reason lies in that V2 may render a subjective reading. Since the scalar property depends on the 
second constituent, the V-V can take the lower closed-scale AP 旧 jiù 'shabby'. Consequently, (32b) sounds better than (32a).

Lower closed-scale AP + closed-scale V-V

(32) a. *张三 看见 房屋破。

Zhāngsān kànjiàn fáng wū pò

Zhangsan look-see house damaged

'Zhangsan sees the house damaged.'

b. 张三 看见 房屋旧。 (better)

Zhāngsān kànjiàn fáng wū jiù

Zhangsan look-see house shabby

'Zhangsan sees the house shabby.'

Concerning the question of how totally open-scale APs might associate with different layers of perceptual verbs we find out that the combination of [totally open-scale AP + closed-scale perceptual verb] is ill-formed.

Totally open-scale AP + closed-scale perceptual verb
(33)
见他累。
(ill-formed)
Zhāngsān jiàn tā lèi
Zhangsan see him exhausted
'Zhangsan sees him exhausted.'

The combination of [totally open-scale AP + closed-scale perceptual verb] can only be acceptable under the following circumstance:
(34)
34) 张三
见他
累,
就去 安慰
他。
Zhāngsān jiàn tā lèi
jiù qù
ānwèi
tā.
Zhangsan see him exhausted then go comfort him
Seeing him exhausted, Zhangsan (immediately) went to comfort him.

In this regard, the perceptual verb 见 jiàn 'see' is not solely a perceptual verb but also conveys a lexicalised meaning, i.e. 'find, think'. The extra context is obligatory, as it specifies a successive relation of the two events (i.e. as soon as finding him sad/ exhausted/nervous, Zhangsan went to comfort him). The APs, i.e. sad/exhausted/ nervous, in this restricted context are no more open scale.

Totally open-scale APs seem possible to combine with an open-scale perceptual verb. 
Totally open-scale AP + open-scale perceptual verb
(35) 张三
看他累。
(unnatural)
Zhāngsān kàn tā lèi
Zhangsan look him exhausted
'Zhangsan sees him exhausted.'

In addition, totally open-scale APs are not entirely ruled out by the closed-scale perceptual V-V 看见 kànjiàn 'look-see', as can be seen in (36).

Totally open-scale AP + closed-scale perceptual V-V
(36) ?张三 看见 他累。
Zhāngsān kànjiàn tā lèi
Zhangsan look-see him exhausted
'Zhangsan sees him exhausted.'

To summarise, this section addressed the question on how various layers of APs might be treated by three types of Chinese perceptual verbs, i.e. open-scale V: 看 kàn 'look'; closed-scale V: 见 jiàn 'see' and closed-scale V-V 看见 kànjiàn 'look-see'. Findings can be summarised as follows.

First, 看 kàn is open scaled. It fails to combine with lower closed-scale APs or totally closed-scale APs. The degree of 看's association with different layers of APs runs from a totally open-scale AP, down to an upper closed-scale AP, lower closed-scale AP, and totally closed-scale AP. Below are the combinations of 看 kàn with different layers of APs.

The combinations of 看 kàn with four layers of APs.

(37) Totally open-scale AP + Open-scale perceptual V: O

Upper closed-scale AP + Open-scale perceptual V: ?

Lower closed-scale AP + Open-scale perceptual V: *

Totally closed-scale AP + Open-scale perceptual V: *

Second, 见 jiàn bears a closed-scale character and is likely to indicate the result of a perceived event. The acceptability of perceptual complements of 见 jiàn is as follows.

The combinations of 见 jiàn with four layers of APs.

(38) Totally closed-scale AP + Closed-scale perceptual V: O

Upper closed-scale AP + Closed-scale perceptual V: ?

Lower closed-scale AP + Closed-scale perceptual V: ?

Totally open-scale AP + Closed-scale perceptual V:

Third, 看见 kànjiàn 'look-see' is a resultative compound verb, where the first constituent 看 kàn denotes the perception action and the second constituent 见jiàn renders the result of the perpetual event. Essentially, the scalar property is determined 
by V2. Thus, 看见 kànjiàn 'look-see' is deemed a closed scale. The combination with different layers of APs is given in (39).

The combinations of V-V 看见 kànjiàn 'look-see' with four layers of APs.

(39) Totally open-scale AP + Closed-scale perceptual V-V: ?

Totally closed-scale AP + Closed -scale perceptual V-V:

Upper closed-scale AP + Closed -scale perceptual V-V:

Lower closed-scale AP + Closed-scale perceptual V-V:?

\section{Adjective distribution in a resultative construction}

Having drawn the picture of adjective distribution in direct perception expressions, this section moves on to see how adjectival complements are treated by resultatives. To begin with, there are four argument structures of resultatives in Chinese, namely,

The variation of argument structure of Chinese resultative constructions:

(40) [Transitive verb + AP];

[Unergative verb + AP];

[Light verb + AP];

[Unaccusative verb $+\mathrm{AP}]$.

Crucially, both inherent and derived resultatives in Chinese are licensed. In the following discussions, we shall look into the distribution of adjectives in these two types of resultatives. Consider adjectives in inherent resultatives first, c.f. (41)-(44).

\subsection{Adjectives in inherent resultatives}

Totally closed-scale AP

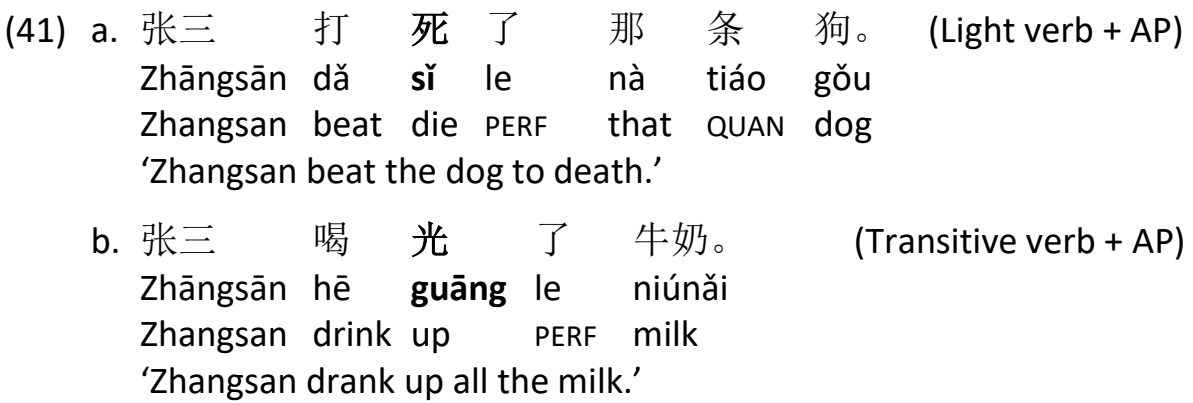


Totally open-scale AP
(42)
a. 张三 拉 长了 绳子 ${ }^{5}$ (Transitive verb + AP)
Zhāngsān lā cháng le shéngzi
Zhangsan stretch long PERF rubber
'Zhangsan stretched the rubber long.'
b. 张三 挖深了井。
Zhāngsān wā shēn le jǐng
Zhangsan dig deep PERF well
'Zhangsan dug the well very deep.'
(Transitive verb + AP)

Lower closed-scale AP
(43)
a. 张三打 破了花瓶。
Zhāngsān dă pò le huāpíng
Zhangsan LIGHT V. broken PERF vase
'Zhangsan broke the vase.'
b. 张三 哭湿了手帕。 (Unergative verb + AP)
Zhāngsān kū shī le shǒupà
Zhangsan cry wet PERF handkerchief
'Zhangsan cried and made the handkerchief wet.'

\author{
(Light verb + AP)
}

Upper closed-scale AP
(44) 冰箱 冻
bīngxiāng dòng yìng le shuǐ jiăo
Refrigerator freeze solid PERF dumpling
'The refrigerator froze the dumpling solid.'
(Transitive verb + AP)

Verb compounds play a significant role in Modern Chinese. Following Dexi Zhu (1982, pp. 32-33), there are five variations, i.e. (a) subject-predicate type; (b) predicate-object type; (c) modifier-predicate type; (d) predicate-complement type; (e) coordinate type.
(45) a. [predicate-complement type]
dă-pò 'hit-broken'
b. [modifier-head type]
zhuī-shā 'chase-kill'
c. [subject-predicate type]
tóu-téng 'have a headache'
d. [paratactic structure type]
pái-huái 'wander'
e. [predicate-object type]
chōng-diàn 'charge'

Among them, the (d) predicate-complement type can be associated with resultatives. The first constituent does not imply an accomplishment or an achievement. The second constituent plays the role of resultative complement, expressing a state or the result

\footnotetext{
${ }^{5}$ The examples (46)-(49) are taken from Ma and Lu (1997a).
} 
of an action. In this study, we consider the second constituents are adjectives ${ }^{6}$. Essentially, the resultative complements are framed outside verb roots and are therefore not restricted. All layers of APs appear to be licensed to denote a result.

\subsection{Adjectives in derived resultatives}

Next, we engage into the data of adjectival complements in derived resultatives, c.f. (46)-(49).

Totally open-scale AP

$\begin{array}{llllllll}\text { (46) a. 张三 吃 } & \text { 穷 } & \text { 了 } & \text { 这 } & \text { 个 } & \text { 家。 } & \text { (Transitive verb + AP) } \\ \text { Zhāngsān chī qióng } & \text { le } & \text { zhè gè } & \text { jiā } & \\ \text { Zhangsan eat poor } & \text { PERF the QUAN family } & \end{array}$
'Zhangsan spent too much money on food and finally the family went broke.'
b. 张三
(干活)
干 累
了。
(Light verb + AP)
Zhāngsān (gàn huó) gàn lèi
le
Zhangsan do-work do exhausted PERF
'Zhangsan got tired from work.'

Totally closed-scale AP

\begin{tabular}{|c|c|c|c|c|c|c|}
\hline (47) a. & $\begin{array}{l}\text { a. 屋子 } \\
\text { wūzǐ } \\
\text { room } \\
\text { 'The roc }\end{array}$ & $\begin{array}{l}\text { 里 坐 } \\
\text { lĩ zuò } \\
\text { inside sit } \\
\text { om is full of } F\end{array}$ & $\begin{array}{l}\text { 满 } \\
\text { măn } \\
\text { full } \\
\text { etition }\end{array}$ & $\begin{array}{l}\text { 了 } \\
\text { le } \\
\text { PERF } \\
\text { ners.' }\end{array}$ & $\begin{array}{l}\text { 上访者。 } \\
\text { shàngfăngzhě } \\
\text { petitioner }\end{array}$ & (Unaccusative ver \\
\hline & $\begin{array}{l}\text { b. A 股 } \\
\text { A gǔ } \\
\text { A share } \\
\text { 'A share }\end{array}$ & $\begin{array}{l}\text { 市场 } \\
\text { shìchăng } \\
\text { market } \\
\text { market sh }\end{array}$ & $\begin{array}{l}\text { 做 } \\
\text { zuò } \\
\text { do }\end{array}$ & $\begin{array}{l}\text { 空 } \\
\text { kōng } \\
\text { empty } \\
\text { unit.' }\end{array}$ & $\begin{array}{l}\text { 问题股。 } \\
\text { wèntí gǔ } \\
\text { unit }\end{array}$ & (Light verb + AP) \\
\hline
\end{tabular}

Lower closed-scale AP
(48)
a. 张三 害三苦了李四。
Zhāngsān hài kǔ le Lǐsì
Zhangsan impair bitter PERF Lisi
'Zhangsan has put Lisi in a bind.'

\footnotetext{
${ }^{6}$ The category of the complements is debatable. Li and Thompson et al. (1981) regard them as adjectives. Palmer (2005) argues that they are stative verbs. This study is in support of Li and Thompson et al's. (1981) point of view for the following reason. First, the combination of this type of $\mathrm{V}$ - $\mathrm{V}$ is very productive. All layers of APs are possible combine with an act verb, which also has a variety, i.e. transitive verb, unergative verb, light verb or unaccusative verb are all welcome.
} 
Upper closed-scale AP

(49)

$\begin{array}{lllll}\text { a. 张三 走 } & \text { 平 } & \text { 了 } & \text { (Unergative verb + AP) } \\ \text { Zhāngsān zǒu píng le lù } & \\ \text { Zhangsan walk even PERF road } & \\ \text { 'Zhangsan walked the road even.' }\end{array}$

Like inherent resultatives, which due to resultative complements (V2s) being framed outside the verb roots and thus have a generous acceptance by the first constituents, APs in derived resultatives are of no diverse distribution, i.e. all layers are licensed to indicate result. This displays a different picture to Altaic languages, where derived resultatives are ruled out, c.f. (50).

Derived resultatives in Mongolian

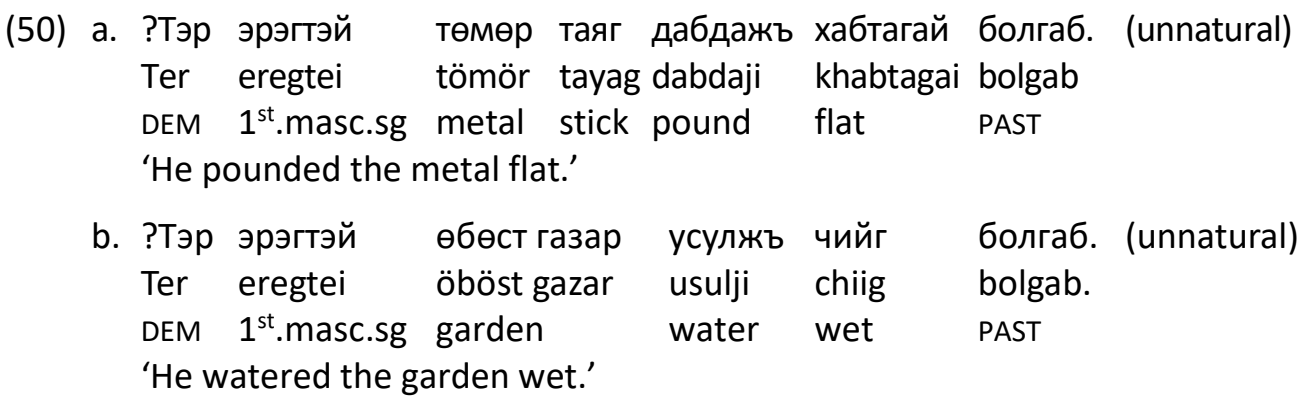

There are two ways to convey derived resultatives in Mongolain. (a) by supplying them with an adverb (e.g. жинхэнэ) to temporarily fill the GAP between CAUSE EVENT and RESULT EVENT. (b) by employing a co-verb construction (c.f. 51) a postpositional phrase (c.f. 52) to render the derived result.

Derived resultatives by co-verb construction

(51) Тэр эмэгтэй уйлаадл байсан.

DEM $1^{\text {st }}$.femi.sg cry-PROG-tired-PAST

'She cried (until she got) tired.'

Derived resultatives by postpositional phrase

(52) Тэр эрэгтэй ус хөлдөөж мөс болгов.

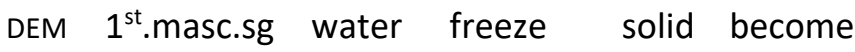
'He froze the water and the water turned into ice.'

Another Altaic language, Japanese, also lacks derived resultatives, c.f. (53a). Verb compounds (c.f. 53b) and postpositional phrase (c.f. 53c) are employed to render derived result. 
Derived resultatives in Japanese

(53)
a. *彼女 は 魚 を
をゼリ一状に
吒いた。
(ill-formed)
Kanojo wa sakana
zerii joo
tataita.
She TOP fish ACC jelly into pound-PAST
'She pounded the fish into a jelly.'

b. 彼女は魚を ゼリ一状に吒き潰した。 (V-V: better)

Kanojo wa sakana o zerii joo ni tataki-tsubushita

She TOP fish ACC jelly into pound-smash-PAST

'She pounded the fish into a jelly.'

c. 彼女は魚をゼリ一状になる まで吒いた。(PP: well-formed)

Kanojo wa sakana o zeriijoo ni naru made tataita.

She TOP fish ACC jelly into become until pound-smash-PAST

'She pounded the fish until it turned into jelly.'

Moreover, as is acknowledged by Beavers, 2002; Levin \& Rappaport, 1995, 1999, and others, Germanic languages license both inherent and derived resultatives. (54)-(55) are illustrations of German and English.

German derived resultatives

(54) Mary tanzte sich müde.

'Mary danced herself tired.'

English derived resultatives

(55) Mary ran herself tired.

The cross-linguistic variation towards derived resultatives is possibly down to the following reason. In Germanic languages as well as in Chinese, the MANNER of ACTION is conveyed by the core verb while the RESULT is rendered via other elements, e.g. a PP, or an AP. Thus, the verb and the result are not necessary associated directly. In other words, the ACTION is not obligatory to lead to the RESULT. On the other hand, in Altaic languages, the verb of resultative constructions has to implicate the RESULT (inherent resultatives), i.e. the RESULT ought to be incorporated into the core verb, otherwise, the construction would become ill-formed (i.e. derived resultatives).

\section{Summary}

This paper has addresses the question on how adjectives distribute in Chinese direct perception expressions and resultatives. We re-classified Chinese monosyllabic adjectives and verbs in light of the scale structure framework. We also looked into how various layers of adjectives get combined with different perceptual/action verbs. The findings can be summarised as follows. 
1. Upper closed-scale APs do not match well with closed-scale perceptual verbs. The ungrammaticality can be corrected by supplying the expression with a tense or a syntactic context.

2. The combination of [upper closed-scale AP + open-scale perceptual V] appears ill-formed. The progressive marker 着 zhe may enable the upper closed-scale AP to transit temporarily into an open-scale AP. Thus, the event turns into a totally open-scale perceiving event.

3. Upper closed-scale APs may be possible to associate with closed-scale perceptual V-V.

4. It is not very likely that open-scale perceptual verbs would combine with totally closed-scale APs.

5. The closed-scale perceptual V-V may form with totally closed-scale APs.

6. A lower closed-scale AP does not seem capable of associating with closedscale perceptual verbs.

7. Open-scale perceptual verbs fail to combine with lower closed-scale APs.

8. The combination of V-V and lower closed-scale APs is natural.

9. The lower closed-scale AP seems unable to combine with the closed-scale V-V.

10. The combination of [totally open-scale AP + closed-scale perceptual verb] is ill-formed.

11. It is odd to combine totally open-scale APs with open-scale perceptual verbs.

12. Totally open-scale APs can well form with the closed-scale perceptual V-V.

To summarise, the degree of open-scale perceptual verb 看 kàn's association with different layers of APs runs from totally open-scale AP down to upper closed-scale AP, lower closed-scale AP, and totally closed-scale AP. The acceptability of APs by the closed-scale perceptual verb 见 jiàn runs from totally closed-scale AP down to upper closed-scale AP, lower closed-scale AP and totally open-scale AP. 看见 kànjiàn ('looksee') is deemed closed-scale, and its combinations with different layers of APs is relatively loose.

Syntactically, the perceptual complement taken by the closed-scale perceptual verb 见 jiàn does not represent a RESULT STATE, as the AP-complement is encoded in the perception verb root and thus has to be interpreted as a whole predication denoting evaluative interpretation. In this regard, 见 jiàn ('see') is subjective. In contrast, the open-scale perceptual verb 看 $k$ àn ('look') renders a direct perception report. It does not describe the observer's conceptualisation of the perceived event and is thus alleged to be objective. 
Resultatives may welcome all layers of adjectives. Various APs may match with a transitive verb, an unergative verb, a light verb or an unaccusative verb. This is because the resultative complements are framed outside the verb roots and are thus not restricted. Nonetheless, syntactically, a closed-scale AP serves as an accomplishment predicate and thus contains an event argument in its lexical representation. The expression is an EVENTUALITY. On the other hand, an open-scale AP serves as a stative predicate, and the subclause is not an EVENTUALITY.

The distribution of adjectives in resultative and direct perception expressions are summarised in Table 2 and Table 3.

Table 2: Adjective distribution in Chinese resultatives

\begin{tabular}{lccc}
\hline AP & $\begin{array}{c}\text { Open-scale } \\
\text { action V }\end{array}$ & $\begin{array}{c}\text { Upper closed-scale } \\
\text { action V }\end{array}$ & $\begin{array}{c}\text { Totally closed-scale } \\
\text { action V }\end{array}$ \\
\hline Totally open scale & 0 & $\circ$ & 0 \\
Lower closed scale & 0 & 0 & 0 \\
Upper closed scale & 0 & 0 & 0 \\
Totally closed scale & 0 & $\circ$ & $\circ$ \\
\hline
\end{tabular}

Table 3: Adjective distribution in Chinese direct perception expressions

\begin{tabular}{lccc}
\hline AP & $\begin{array}{c}\text { Open-scale } \\
\text { perceptual V }\end{array}$ & $\begin{array}{c}\text { Closed-scale } \\
\text { perceptual V }\end{array}$ & $\begin{array}{c}\text { Closed-scale } \\
\text { perceptual V-V }\end{array}$ \\
\hline Totally open scale & 0 & $\times$ & 0 \\
Lower closed scale & $\times$ & $?$ & $?$ \\
Upper closed scale & $?$ & $?$ & 0 \\
Totally closed scale & $\times$ & 0 & 0 \\
\hline
\end{tabular}

\section{References}

Beavers, J. (2008). Scalar complexity and the structure of events. In J. Dölling, T. Heyde-Zybatow \& Martin Schäfer (Eds.). Event structures in linguistic form and interpretation (245-265). Berlin: de Gruyter.

Bolinger, D. (1972). Degree Words. The Hague: Mouton.

Chao, Y. (1948). Mandarin primer: An intensive course in spoken Chinese. Cambridge, MA: Harvard.

Chao, Y. (1968). A Grammar of Spoken Chinese. Berkeley: University of California Press.

Dimitrova-Vulchanova, M. (2016). On two types of results: resultatives revisited. Trondheim: NTNU. 
Hay, J., Kennedy, C., \& Levin B. (1999). Scalar structure underlies telicity in 'degree achievements'. Semantics and Linguistic Theory 9, 127-144.

Karlgren, B. (1949). The Chinese language. New York: Ronald Press.

Kennedy, C. (1999). Projecting the Adjectives: The Syntax and Semantics of Gradability and Comparison. New York: Garland.

Kennedy, C. \& McNally, L. (2005). Scale structure, degree modification, and the semantics of gradable predicates. Language, 81(2), 345-381.

Ma, J. (1898). Mashi Wentong. Reprint Shanghai: Shangwu yinshuguan 1925.

Maspero, H. (1934). La langue chinoise. In Conferences de I'Institut de linguistique de I'Universite de Paris. Année 1933. Paris: Boivin et Cie.

Packard, J. (2000). The Morphology of Chinese. New York: Cambridge University Press.

Sapir, E. (1944). Grading: a study in semantics. Philosophy of Science (11), 93-116.

Vendler, Z. (1967). Linguistics in Philology. Cornell University Press.

Wang, L. (1957-58). Hanyu shi gao. 3 vols. Beijing: Kexue yuan.

Wechsler, S. (2005). Resultatives under the 'event-argument homomorphism' model of telicity. In N. Erteschik-Shir \& T. Rapaport (Eds.). The syntax of aspect. Oxford: Oxford University Press. 255-274.

Zhu, D. (1982). Yufa Jiangyi [Lectures on Grammar]. Beijing: The Commercial Press.

\section{Abbreviations}

DEM demonstrative

EXCL exclamatory

$1^{\text {st. }}$.masc.sg first personal pronoun, singular, masculine

NLZR nominaliser

PERF perfective

QUAN quantifier 